\title{
PENGARUH KATALIS Co DAN Fe TERHADAP KARAKTERISTIK CARBON NANOTUBES DARI GAS ASETILENA DENGAN MENGGUNAKAN PROSES CATALYTIC CHEMICAL VAPOUR DEPOSITION (CCVD)
}

\author{
Tutuk Djoko Kusworo ${ }^{*}$, Desmila Yusufina, dan Atyaforsa \\ ${ }^{1)}$ Jurusan Teknik Kimia, Fakultas Teknik, Universitas Diponegoro \\ Jl. Prof. Sudarto, Tembalang-Semarang, 50275, Telp/fax: (024)7460058/(024)76480675 \\ ${ }^{2)}$ Program Studi Teknik Kimia Fakultas Teknik Universitas Wahid Hasyim \\ Jl. Menoreh Tengah X/22, Sampangan, Semarang, Telp. (024)8505680 \\ ${ }^{*}$ Penulis korespondensi : tutukjoko@yahoo.com
}

\begin{abstract}
EFFECT OF Co AND Fe ON CARBON NANOTUBES CHARACTERISTICS FROM ACETYLENE USING CATALYTIC CHEMICAL VAPOUR DEPOSITION (CCVD) PROCESS. Carbon Nanotubes (CNTs) is one of the most well known nano-technology applications which the most of attracting the attention of researchers, because it has more advantages than other materials. The application of the CNT has extended into various aspects, such as electronics, materials, biology and chemistry. This research uses a system of Catalytic Chemical Vapour Deposition (CCVD), which aims to determine the influence of Co and Fe as a catalyst and zeolite 4A as a support catalyst with acetylene gas $\left(\mathrm{C}_{2} \mathrm{H}_{2}\right)$ as carbon source in the synthesis of Carbon Nanotubes (CNTs). In this experiment, used the ratio of acetylene gas and flow rate of $\mathrm{N}_{2}$ gas is 1:1 by weight of the catalyst Co/Zeolite and Fe/Zeolite amounted to 0.5 grams at the operating temperature of $700^{\circ} \mathrm{C}$ for 20 minutes. $N_{2}$ gas serves to minimize the occurrence of oxidation reaction (explosion) when operating. From analysis result by Scanning Electron Microscopy (SEM) shows the CNTs formed a type of MWNT with different of diameter size and product weight, depending on the size of the active component concentration on the catalyst. The larger of active components produced CNTs with larger diameter, whereas product weight syntheses result smaller. Use of the catalyst Fe/Zeolite produce CNTs with a diameter larger than the catalyst Co/Zeolite.
\end{abstract}

Keywords: carbon nanotubes; characteristic; chemical vapour deposition; cobalt; ferrum

\begin{abstract}
Abstrak
Carbon Nanotubes (CNTs) merupakan salah satu aplikasi nanoteknologi yang paling terkenal dan banyak menarik perhatian para peneliti, karena memiliki beberapa kelebihan daripada material lainnya. Aplikasi dari CNT telah merambah ke berbagai aspek, seperti bidang elektronika, material, biologi dan kimia. Penelitian ini menggunakan sistem Catalytic Chemical Vapour Deposition (CCVD) yang bertujuan untuk mengetahui pengaruh variasi Cobalt (Co) dan Ferrum (Fe) sebagai katalis dan zeolit tipe 4A sebagai penyangga katalis dengan gas asetilen $\left(\mathrm{C}_{2} \mathrm{H}_{2}\right)$ sebagai sumber karbon dalam sintesis carbon nanotubes (CNTs). Pada penelitian ini digunakan perbandingan laju alir gas asetilen dan gas $\mathrm{N}_{2}$ yaitu 1:1 dengan berat katalis Co/Zeolit dan Fe/Zeolit masing-masing sebesar 0,5 gram pada suhu operasi $700{ }^{\circ} \mathrm{C}$ selama 20 menit. Dari hasil analisa Scanning Electron Microscopy (SEM) menunjukkan CNTs yang dihasilkan pada penelitian ini memiliki tipe Multi Walled Nano Tube (MWNT) dengan ukuran diameter dan berat produk yang berbeda, tergantung dari besarnya konsentrasi komponen aktif pada katalis. Semakin besar konsentrasi komponen aktif akan dihasilkan CNTs dengan diameter yang semakin besar, sedangkan berat produk semakin kecil. Penggunaan katalis Fe/Zeolit dengan kalsinasi akan menghasilkan CNTs dengan diameter yang lebih besar daripada katalis Co/Zeolit.
\end{abstract}

Kata kunci: karbon nanotube; karakteristik; chemical vapour deposition; cobalt; ferrum 


\section{PENDAHULUAN}

Nanoteknologi merupakan ilmu pengetahuan dan teknologi yang baru dan menarik. Dari segi bahasa, istilah "nano" diambil dari ukuran suatu benda/material dalam skala nanometer. Satu nanometer adalah satu per satu milyar meter $\left(10^{-9} \mathrm{~m}\right)$. Ukuran ini sudah berdekatan dengan ukuran satu atom yang berukuran beberapa amstrong saja (1 amstrong sama dengan sepersepuluh nanometer). Untuk perbandingan, kita bisa mengibaratkan antara besar bumi yang berdiameter kurang lebih 13 ribu kilometer dengan kelereng yang hanya berdiameter $1,3 \mathrm{~cm}$. Terobosan yang sebenarnya pada penelitian Nanoscience hadir melalui pengamatan eksperimental karbon nanotube pada tahun 1991 oleh Iijima dari Laboratorium NEC (National Electrostatic Corporation) di Tsukaba, Jepang menggunakan transmisi mikroskop elektron resolusi tinggi (HRTEM) (Iijima, 1991). Meskipun penemuan CNT lebih lambat dibandingkan fullerene, namun aplikasinya lebih cepat direalisasikan. Ini disebabkan karena teknologi pengontrolan posisi CNT pada suatu obyek lebih cepat ditemukan sebagai contoh teknologi untuk alat field-electron emitter (FE) (Kusumadewi, 2005), telah dapat digunakan sebagai material penyerap dan penyimpan gas hidrogen, yang merupakan material yang diperlukan dalam pembuatan fuel cell (Nuryadi, 2006).

Beberapa metode dikembangkan untuk menghasilkan karbon nanotube dengan kualitas yang unggul di antaranya; electric arc discharge, laser ablation dan catalytic chemical vapour deposition (CCVD) (Baker dkk., 1973). Aplikasi CNTs dalam Industri memerlukan produksi CNTs dalam skala besar sehingga sangat diharapkan CNTs dapat diproduksi dengan biaya murah. Pembuatan CNTs dengan menggunakan metode arc discharge dan laser ablation menghasilkan kualitas yang baik dan kemurnian yang tinggi namun memerlukan biaya yang besar dalam proses produksinya sehingga tidak efektif untuk diproduksi dalam jumlah besar dalam skala industry (Guo dkk., 1995). Dari hasil beberapa penelitian, dilaporkan bahwa pembuatan CNTs dengan menggunakan metode CCVD dapat menghasilkan karbon nanotube dengan kualitas yang baik dan biaya produksi yang murah karena dapat dilakukan pada suhu yang rendah (Laurent dkk., 1998; Wei dkk., 2001). Prinsip penumbuhan nanotube karbon dengan metode CCVD adalah dekomposisi termal senyawa hidrokarbon dengan bantuan katalis partikel metal. Logam transisi dengan konfigurasi electron 3d diketahui dapat digunakan sebagai penyangga katalis dengan efisiensi yang tinggi untuk menghasilkan SWNTs dan MWNTs. Peran dari penyangga katalis yang meliputi dispersi partikel logam pada penumbuhan karbon nanotube disampaikan oleh Colomer dkk. (1999). Pada penelitian ini, karbon nanotube terbentuk dengan adanya proses dekomposisi senyawa hidrokarbon yang menggunakan gas asetilen sebagai sumber karbon dengan bantuan metal transisi sebagai katalis. Pada teknik CCVD banyak menggunakan sumber hidrokarbon sebagai bahan bakunya, seperti: metana, etylene, acetylen atau benzene, dan lain-lain (Tee dkk., 2008; Tee dkk., 2009). Beberapa peneliti menyampaikan bahwa partikel katalis memiliki peranan penting dalam penumbuhan karbon nanotubes (Audier dkk., 1996; Wei dkk., 2001; Tee dkk., 2008). Suhu operasi merupakan salah satu faktor lain yang memegang peranan pada pertumbuhan karbon nanotubes. Tee dkk. (2009) menyampaikan bahwa suhu operasi yang cukup tinggi pada sistem CCVD akan dihasilkan karbon nanotubes dengan tipe single wall carbon nanotubes (SWNTs). Sumber karbon yang dipilih adalah gas asetilena, yang merupakan senyawa yang mudah di dekomposisi. Selain itu, gas asetilen merupakan senyawa hidrokarbon yang paling sering digunakan sebagai sumber karbon dalam pembuatan karbon nanotubes dengan menggunakan metode CCVD. Peranan katalis pada proses pertumbuhan carbon nanotubes pada proses CCVD adalah untuk mempercepat serta mengarahkan reaksi. Katalis yang biasa digunakan pada sistem catalytic chemical vapour deposition (CCVD) adalah $\mathrm{Fe}, \mathrm{Co}, \mathrm{Ni}, \mathrm{Cr}, \mathrm{V}$, Mo, Pt, Mg, Si (Audier dkk., 1996; Tee dkk., 2009). Sejauh penelusuran referensi yang dilakukan untuk mendukung kebaruan dalam dalam penelitian ini maka akan dirancang serta dibuat sistem CCVD yang dapat beroperasi pada suhu yang rendah untuk menghasilkan karbon nanotubes dengan kualitas yang baik. Kelebihan yang lain pada sistem ini adalah menggunakan katalis dan penyangga katalis dari material yang relatif murah serta mudah didapatkan yaitu cobalt dan ferrum serta zeolite sebagai penyangga katalis.

\section{METODE PENELITIAN \\ Bahan dan Peralatan}

Pada penelitian yang dilakukan digunakan gas Asetilen $\left(\mathrm{C}_{2} \mathrm{H}_{2}\right)$ yang diperoleh dari PT. Samator, digunakan sebagai sumber karbon untuk pertumbuhan karbon nanotubes serta gas nitrogen $\left(\mathrm{N}_{2}\right)$ sebagai inert gas. Katalis aktif yang digunakan adalah $\mathrm{Co}\left(\mathrm{NO}_{3}\right)_{2} 6$ $\mathrm{H}_{2} \mathrm{O}$ (Merck) dengan kemurnian $98 \%$ dan $\mathrm{Fe}\left(\mathrm{NO}_{3}\right)_{3} 9$ $\mathrm{H}_{2} \mathrm{O}$ (Sigma-Aldrich) dengan kemurnian 99\% serta sebagai penyangga katalis digunakan zeolite 4A (Sigma-Aldrich). Dalam penelitian ini digunakan sistem Catalytic Chemical Vapour Deposition (CCVD). Rangkaian sistem CCVD terdiri dari furnace dengan dimensi, panjang $45 \mathrm{~cm}$ dan diameter dalam 4 $\mathrm{cm}$. Di dalam furnace diletakkan tabung stainless steel yang berukuran diameter $3,5 \mathrm{~cm}$ dan panjang 75 $\mathrm{cm}$ yang berfungsi sebagai reaktor di mana dalam tabung ini diletakkan cawan kecil dengan dimensi panjang $7 \mathrm{~cm}$, tinggi dan lebar cawan $1 \mathrm{~cm}$ sebagai tempat katalis dan juga tempat pertumbuhan karbon nanotubes. Karbon nanotubes yang dihasilkan terkumpul dalam cawan. Selain furnace juga digunakan mixing gas yang berfungsi untuk mencampur gas asetilen dan gas nitrogen yang 
dilengkapi dengan flowmeter untuk mengatur laju alir gas. Untuk mengalirkan gas asetilen dan nitrogen ke tabung stainless steel digunakan selang NCR. Setelah 20 menit operasi dengan suhu $700{ }^{\circ} \mathrm{C}$ terbentuk CNTs yang berada dalam stainless steel. CNTs yang dihasilkan akan dianalisa menggunakan Scanning Electron Microscopy (SEM). Rangkaian peralatan utama sistem CCVD untuk proses pembentukan carbon nanotubes (CNTs) dapat dilihat pada Gambar 1.

\section{Prosedur Penelitian}

Penelitian dimulai dengan proses penyiapan katalis. Katalis yang digunakan adalah $\mathrm{Co}\left(\mathrm{NO}_{3}\right)_{2}$ dan $\mathrm{Fe}\left(\mathrm{NO}_{3}\right)_{3}$, serta penyangga yang digunakan adalah zeolit 4A dengan ukuran partikel sesuai dengan variabel. Untuk meningkatkan aktivitas dan luas permukaannya perlu dilakukan aktivasi yaitu pembuatan $\mathrm{H}$-zeolit. Zeolit tersebut dicampur dengan larutan $\mathrm{NH}_{4} \mathrm{NO}_{3}$ lalu dilakukan pengadukan. Kemudian disaring dan dicuci dengan aquadest, selanjutnya dikeringkan dalam oven. Katalis dan material penyangga dicampurkan dengan menggunakan aquadest, kemudian larutan diaduk selama \pm 4 jam menggunakan magnetic stirer hingga homogen. Setelah didapatkan larutan yang homogen, langkah selanjutnya adalah dikeringkan dalam oven pada suhu $110^{\circ} \mathrm{C}$ selama \pm 10 jam. Dalam hal ini bertujuan untuk menguapkan air. Larutan di kalsinasi dengan menggunakan oven pada suhu $500^{\circ} \mathrm{C}$ selama \pm 5 jam. Pembuatan karbon nanotubes dalam penelitian ini dengan metode CCVD (Catalytic Chemical Vapor Deposition).

Reaktor yang digunakan adalah berupa furnace, yang mana harus dipersiapkan terlebih dahulu. Katalis yang telah dibuat diletakkan dalam kotak cawan kecil lalu kotak tersebut dimasukkan ke dalam furnace. Setelah itu cawan tempat katalis diletakkan dan diatur sedemikian rupa supaya tepat berada di tengah furnace. Suhu furnace diatur sesuai dengan suhu yang diinginkan yaitu $700^{\circ} \mathrm{C}$. Pada saat suhu reaktor mencapai $650^{\circ} \mathrm{C}$, gas Nitrogen mulai dialirkan untuk menghilangkan gas oksigen yang ada di reaktor agar tidak terjadi ledakan. Setelah furnace mencapai suhu yang diinginkan, maka gas asetilen mulai dialirkan ke reaktor selama 20 menit. Karbon nanotubes yang terbentuk akan menempel di permukaan katalis sehingga produk CNTs yang dihasilkan masih bercampur dengan katalis. Kemudian dilakukan analisa dengan alat SEM (Scanning Electron Microscopy) untuk mengetahui struktur morfologi karbon yang terbentuk.

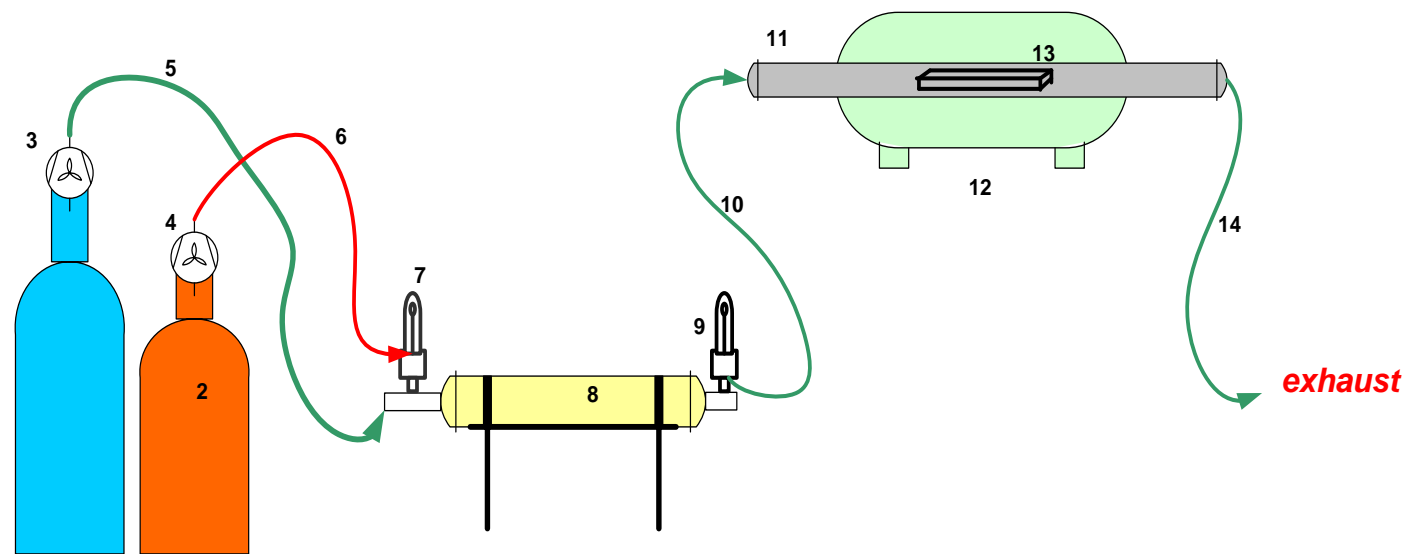

Keterangan :
1.Tabung gas Nitrogen
8. Mixing gas
2.Tabung gas Asetilen
9. Flowmeter mixing gas
3.Regulator Nitrogen
10. Selang mixing gas
4.Regulator Asetilen
11. Tabung stainless steel
5.Selang gas Nitrogen
12. Furnace
6.Selang gas Asetilen
13. Wadah katalis (produk)
7.Flowmeter gas Asetien
14. Selang exhaust

Gambar 1. Skematik alat utama sistem Catalytic Chemical Vapour Deposition (CCVD) pada proses pembentukan CNTs 


\section{HASIL DAN PEMBAHASAN \\ Pengaruh Kalsinasi dalam Sintesis Carbon Nanotubes (CNTs) dari Gas Asetilen dengan Metode Catalytic Chemical Vapour Deposition (CCVD)}

Pada penelitian ini dilakukan sintesis CNTs dengan metode CCVD menggunakan gas asetilen $\left(\mathrm{C}_{2} \mathrm{H}_{2}\right)$ sebagai sumber karbon, katalis $\mathrm{Co} / \mathrm{Zeolit}$ dan Fe/Zeolit dengan komposisi masing-masing sebanyak 3 wt\% dengan perlakuan yang berbeda yaitu dengan kalsinasi dan tanpa kalsinasi. Sebelum proses penumbuhan CNTs pada sistem CCVD, terlebih dahulu gas $\mathrm{N}_{2}$ dialirkan ke dalam reaktor. Pengaliran gas $\mathrm{N}_{2}$ dilakukan pada saat suhu furnace mencapai $650{ }^{\circ} \mathrm{C}$. Pengaliran gas nitrogen ini bertujuan untuk menghilangkan oksigen yang terdapat dalam reaktor stainless steel sehingga dapat meminimalisir terjadinya reaksi oksidasi dalam proses penumbuhan karbon nanotubes. Setelah tercapai suhu $700{ }^{\circ} \mathrm{C}$, gas asetilen dialirkan ke dalam reaktor. Perbandingan antara laju alir gas asetilen dan gas nitrogen yang digunakan adalah sebesar 1:1 selama 20 menit. Zaretskiy dkk. (2003) telah melakukan sintesis CNTs dengan mengalirkan gas asetilen ke dalam furnace setelah pre-treatment selama 15-20 menit dan telah menghasilkan CNTs dengan yield tinggi. Ketika gas asetilen di alirkan dalam furnace yang telah dipanaskan, molekulnya akan putus secara termal dan terjadi reaksi dehidrogenasi dalam proses tersebut sehingga dalam fasa uap membentuk lapisan grafit yang menempel pada permukaan katalis. Ketika suhu operasi diturunkan akan terjadi perubahan fasa menjadi bentuk padat yaitu carbon nanotube (Wang, 2006). Pengaruh kalsinasi pada katalis yang digunakan terhadap proses penumbuhan karbon nanotubes dalam sistem CCVD dapat dilihat pada Tabel 1. Pada Gambar 2a-b terlihat pada $5 \mu \mathrm{m}$ ditunjukan pada ukuran $1.5 \mathrm{~cm}$ sehingga diameter carbon nanotubes adalah sekitar $300 \mathrm{~nm}$ dan $160 \mathrm{~nm}$.

Proses kalsinasi pada katalis yang digunakan akan memberikan pengaruh yang berbeda pada proses pertumbuhan karbon nanotubes pada reaktor dengan sistem Catalytic Chemical Vapour Deposition. Pada katalis yang terkalsinasi akan terbentuk CNTs dengan tipe yang sama yaitu MWNT, sedangkan pada katalis tanpa kalsinasi tidak terbentuk CNT (Tee dkk., 2008 dan Tee dkk., 2009). Pada proses ini, kalsinasi katalis merupakan salah satu parameter penting pada penyiapan katalis untuk proses pertumbuhan karbon nanotubes. Kalsinasi mempengaruhi struktur dan sifat katalis yang berhubungan dengan aktifitas katalitik. Pada pembahasan berikutnya, seperti yang terlihat di Gambar 2 yang merupakan hasil foto SEM dapat dilihat secara jelas perbedaan dari katalis Co/Zeolit dan Fe/Zeolit terkalsinasi dengan $\mathrm{Co} /$ Zeolit dan Fe/Zeolit tidak terkalsinasi.

Tabel 1. Hasil sintesis CNTs dengan katalis kalsinasi dan katalis tanpa kalsinasi

\begin{tabular}{lccc}
\hline \multicolumn{1}{c}{ Jenis Katalis } & Berat Produk (gram) & Tipe CNTs & Diameter (nm) \\
\hline Co/zeolit 3\% (Kalsinasi) & 1,14 & MWNT & 300 \\
Fe/zeolit 3\% (Kalsinasi) & 1,2 & MWNT & 160 \\
Co/zeolit 3\% (tanpa kalsinasi) & 0,68 & - & - \\
Fe/zeolit 3\% (tanpa kalsinasi) & 0,73 & - & - \\
\hline
\end{tabular}
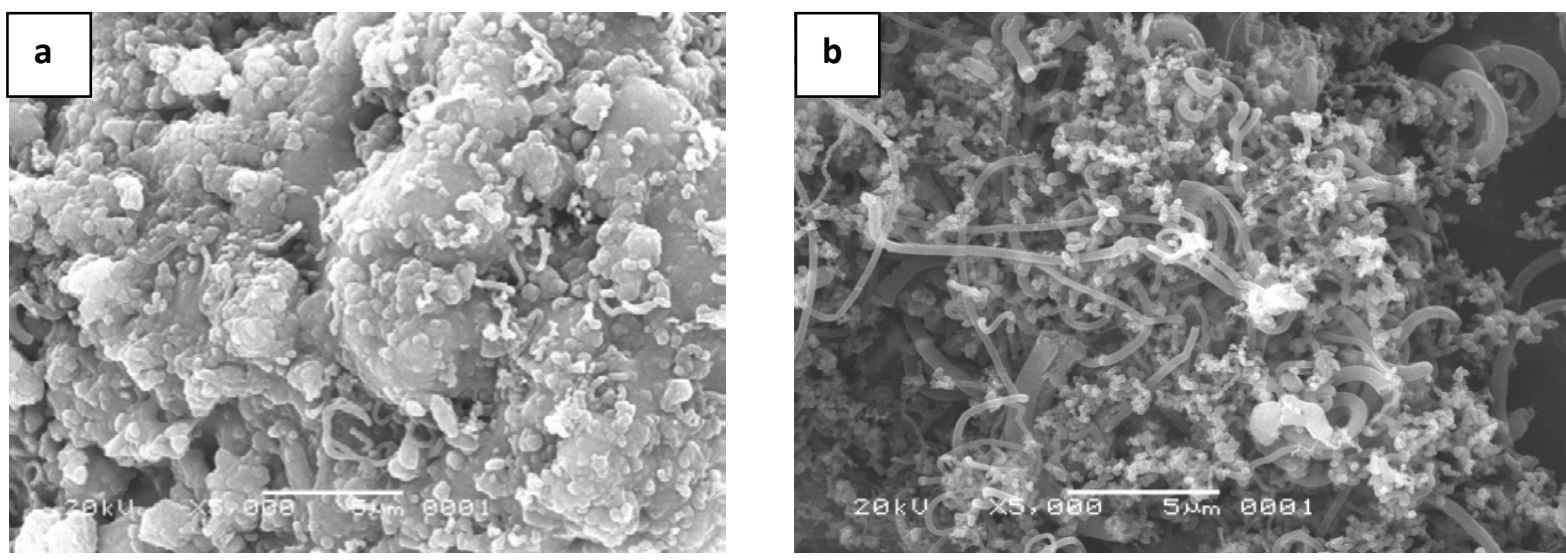

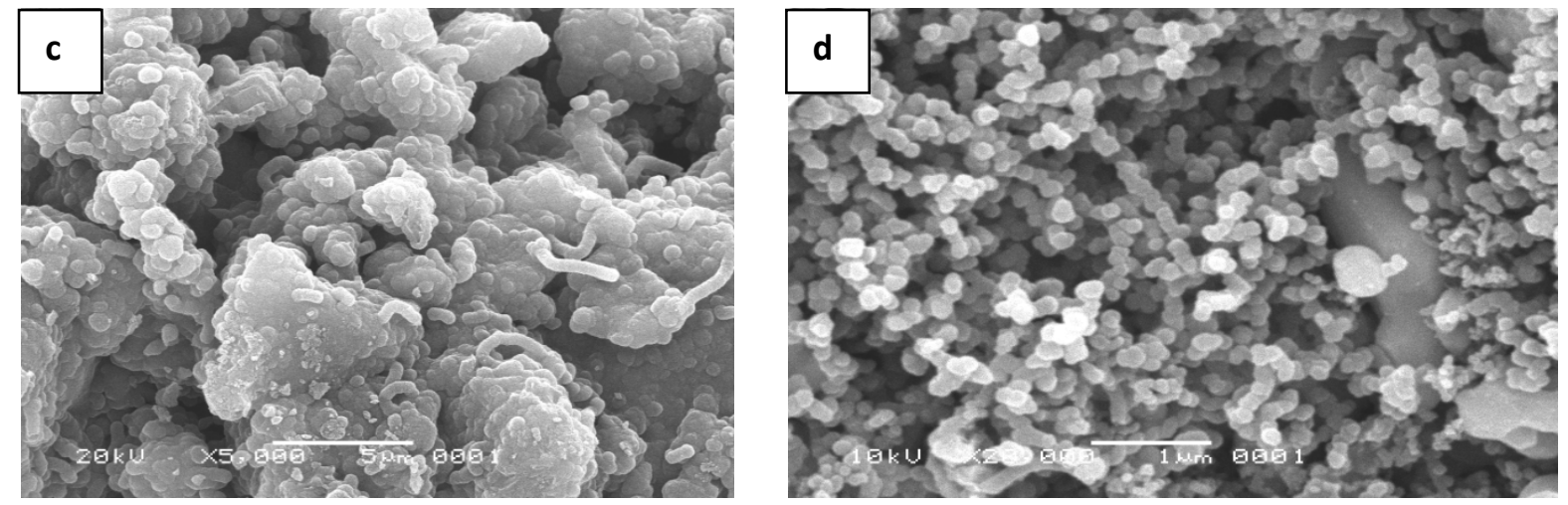

Gambar 2. Hasil foto SEM CNT dengan (a) katalis Co/Zeolit 3\% terkalsinasi, (b) katalis Fe/Zeolit 3\% terkalsinasi, (c) katalis Co/Zeolit 3\% tanpa kalsinasi, (d) katalis Fe/Zeolit 3\% tanpa kalsinasi dengan perbesaran 5000x.

Merujuk pada penelitian sebelumnya yang dilakukan oleh Lee dkk. (2001) dan Chiangga dkk. (2009), maka hasil analisa SEM yang ditunjukan oleh Gambar 2a dan 2b merupakan CNTs dengan tipe multiwalled (MWCNs). Proses pembuatan CNTs dengan menggunakan katalis yang terkalsinasi akan menghasilkan struktur pipa-pipa tubular yang menandai terbentuknya CNTs (Guo dkk., 1995; Zheng dkk., 2002). Pada Gambar 2c dan Gambar 2d menunjukkan bahwa sintesis dengan katalis tanpa kalsinasi tidak terbentuk CNTs yang dapat diketahui dengan tidak terbentuknya struktur pipa-pipa tubular. Kalsinasi pada katalis menjadi sangat penting untuk meningkatkan luas permukaan efektifnya sehingga aktivitas katalis akan meningkat. Adanya kalsinasi dapat menghilangkan air yang terjebak dalam pori katalis, perubahan distribusi ukuran pori, timbulnya situs aktif pada katalis, dan pengkondisian permukaan katalis. Kalsinasi akan meningkatkan situs aktif pada katalis, sehingga probabilitas reaktan berinteraksi dengan permukaan katalis juga semakin meningkat. Hal ini akan mempengaruhi proses sintesis dapat berjalan dengan optimal (Tee dkk., 2008; Tee dkk., 2009).

Katalis tanpa kalsinasi tidak memiliki situs aktif pada komponen yang dimilikinya (kemungkinan situs aktif yang dimiliki hanya sedikit). Di mana, pada saat proses sintesis, katalis tanpa kalsinasi dimungkinkan akan terjadi proses sintering akibat berkumpulnya partikel-partikel logam secara kompak yang membentuk gumpalan-gumpalan pada permukaan pori pengemban, sehingga menutup sebagian pori dan sisi aktif katalis. Hal ini menyebabkan luas permukaan efektifnya menjadi menurun, sehingga situs aktif pada permukaan katalis akan semakin sedikit (Wardhani, 2008). Oleh karena itu, katalis tidak dapat bekerja dengan baik dan optimal yang mengakibatkan tidak terbentuknya CNT.

\section{Pengaruh Komposisi Penyangga Katalis terhadap Morfologi Karbon Nanotubes}

Pengaruh komposisi penyangga katalis terhadap jumlah produk yang dihasilkan serta morfologi karbon nanotube dapat dilihat pada Tabel 2 serta Gambar 3-4. Pada proses penumbuhan karbon Nanotubes (CNTs) melalui metode CCVD dengan berat katalis $\mathrm{Co} /$ Zeolit dan Fe/Zeolit sebesar 0,5 gram ini dilakukan pre-treatment terlebih dahulu, yaitu ketika furnace mencapai suhu $650^{\circ} \mathrm{C}$, gas nitrogen dialirkan dengan tujuan menghilangkan oksigen dalam stainless steel guna meminimalisir reaksi oksidasi (ledakan). Setelah suhu mencapai $700^{\circ} \mathrm{C}$, gas asetilen ditambahkan menggunakan laju alir gas asetilen dan gas nitrogen sebesar 1:1 selama 20 menit. Zaretskiy dkk. (2003) telah melakukan sintesis CNTs dengan mengalirkan gas asetilen ke dalam furnace setelah pretreatment selama 15-20 menit dan telah menghasilkan CNTs dengan yield tinggi.

Dari Tabel 2, dapat dilihat bahwa katalis Co/Zeolit dan Fe/Zeolit dengan komposisi 3\% menghasilkan berat CNTs yang lebih banyak dibandingkan dengan katalis Co/Zeolit dan Fe/Zeolit dengan komposisi 3,5\%. Hal ini disebabkan karena katalis dengan komposisi $3 \%$ mempunyai jumlah luas permukaan support katalis untuk komponen aktif yang lebih besar dibanding dengan katalis dengan komposisi 3,5 \%, dimana peran penyangga katalis sangat penting yaitu katalis utama didispersikan di permukaan penyangga katalis.

Sehingga zeolit sebagai penyangga katalis yang terdapat pada Co/zeolit dan Fe/Zeolit dengan komposisi 3\% lebih banyak mengikat atom $\mathrm{C}$ dari gas asetilen yang digunakan sebagai sumber karbon.

Tabel 2. Hasil sintesis CNTs dengan katalis Cobalt dan Ferrum yang dikalsinasi

\begin{tabular}{lccc}
\hline \multicolumn{1}{c}{ Jenis Katalis } & Berat Produk (gram) & Tipe CNT & Diameter (nm) \\
\hline Co/zeolit 3\% & 1,14 & MWNT & 200 \\
Co/zeolit 3,5\% & 0,9 & MWNT & 150 \\
Fe/zeolit 3\% & 1,2 & MWNT & 125 \\
Fe/zeolit 3,5\% & 1,02 & MWNT & 100 \\
\hline
\end{tabular}


Penambahan massa support katalis berpengaruh pada kenaikan persentase atom $\mathrm{C}$ dan jumlah nanotube karbon yang terbentuk (Nur dkk., 2009). Namun sebaliknya, ketika komposisi katalis utama sedikit, maka diameter CNTs yang terbentuk kecil. Hal ini dikarenakan fungsi dari komposisi katalis utama hanya bertanggungjawab terhadap reaksi kimia utama untuk menghasilkan CNTs. Jadi dapat disimpulkan bahwa penggunaan komposisi katalis utama yang lebih sedikit dibanding dengan komposisi penyangga katalis akan menghasilkan berat produk CNTs yang lebih berat, namun diameter CNTs yang dihasilkan kecil. Sedangkan hasil SEM CNTs Co/Zeolit 3\% dan 3,5\% dapat dilihat pada Gambar 3. Gambar 3 menunjukkan citra SEM material CNT dengan katalis Co/Zeolit 3\% yang dihasilkan dengan perbesaran $40.000 \mathrm{x}$ mempunyai ukuran diameter sekitar 200 nm. Adrian (2009) menjelaskan bahwa diameter karbon nanotubes yang terbentuk mempunyai diameter lebih dari $50 \mathrm{~nm}$ dapat dikategorikan dalam Multi-Walled Nanotubes (MWNTs). Sedangkan Zheng dkk. (2002) mengemukakan bahwa Single-Walled Nanotubes (SWNTs) berdiameter antara 1,0-1,5nm.

Untuk menentukan distribusi ukuran diameter partikel, seperti halnya yang telah dijelaskan oleh Mikrajuddin dan Khairrurijal (2009) setiap foto SEM memiliki bar skala dengan panjang tertentu dan menjadi acuan penentuan ukuran partikel. Pada Gambar 3, bar yang tertulis panjangnya 0,5 $\mu \mathrm{m}$. Diameter partikel pada Gambar 3.a) diukur menggunakan penggaris adalah $0,4 \mathrm{~cm}$, maka diameter riil partikel tersebut adalah $(0,4 \mathrm{~cm} / 1 \mathrm{~cm}) \mathrm{x}$ $0,5 \mu \mathrm{m}=0,2 \mu \mathrm{m}=200 \mathrm{~nm}$. Dengan cara yang sama, Gambar 3.b) mempunyai diameter riil partikel sebesar $(0,3 \mathrm{~cm} / 1 \mathrm{~cm}) \times 0,5 \mu \mathrm{m}=0,15 \mu \mathrm{m}=150 \mathrm{~nm}$. Demikian pula untuk Gambar 4.a) menunjukkan citra SEM material CNTs dengan katalis Fe/Zeolit 3\% yang dihasilkan dengan berbagai pembesaran perhitungan distribusi diameter riil partikel yaitu $(0,25 \mathrm{~cm} / 1 \mathrm{~cm}) \mathrm{x}$ $0,5 \mu \mathrm{m}=0,125 \mu \mathrm{m}=125 \mathrm{~nm}$. Sedangkan Gambar 5.b) (katalis $\mathrm{Fe} /$ Zeolit 3,5\%) diameter riil partikel tersebut adalah $(0,2 \mathrm{~cm} / 1 \mathrm{~cm}) \times 0,5 \mu \mathrm{m}=0,1 \mu \mathrm{m}=100$ nm.

Dari hasil penelitian terdahulu dan perhitungan ukuran partikel diameter tersebut dapat disimpulkan bahwa hasil CNTs dengan katalis Co/Zeolit dan Fe/Zeolit termasuk dalam tipe Multi-walled Nanotube (MWNTs). Dalam penelitian ini terdapat variasi ukuran diameter tabung dari CNTs yang dihasilkan. Hal ini diduga disebabkan oleh kurang tersebarnya suhu operasi di dalam furnace, sehinga terjadi perbedaan kemampuan tingkat suhu untuk memecah karbon-karbon dari campuran Co/Zeolit dan Fe/Zeolit dan Asetilene. Pada suhu $700-1000^{\circ} \mathrm{C}$ muncul ketidakseragaman ukuran tabung yang dihasilkan (Subagio dkk., 2009).

\section{Pengaruh Promotor Katalis terhadap Jumlah Produk dan Diameter Karbon Nanotubes}

Pengaruh promotor katalis terhadap produk karbon nanotubes serta morfologinya dapat dilihat pada Tabel 2 serta Gambar 3-4. Pada dasarnya penelitian ini menggunakan katalis Co dan Fe karena senyawa tersebut merupakan logam transisi dimana dapat membentuk satu / lebih ion stabil yang punya kemampuan mengubah tingkat oksidasi, dapat mengadsorb substansi yang lain pada permukaan logam, dan dapat mengaktivasi substansi tersebut selama proses berlangsung. Katalis Co dan Fe inilah yang akan berperan sebagai awal mula membentuk struktur tubular pada nanotube karbon. Dari Tabel 2 hasil analisa CNTs dengan membandingkan penggunaan Co/Zeolit dan Fe/Zeolit sebagai katalis dan penyangga katalis dapat di lihat bahwa pada komposisi yang sama, katalis Fe/Zeolit lebih banyak menghasilkan produk CNTs dibandingkan dengan katalis Co/Zeolit.
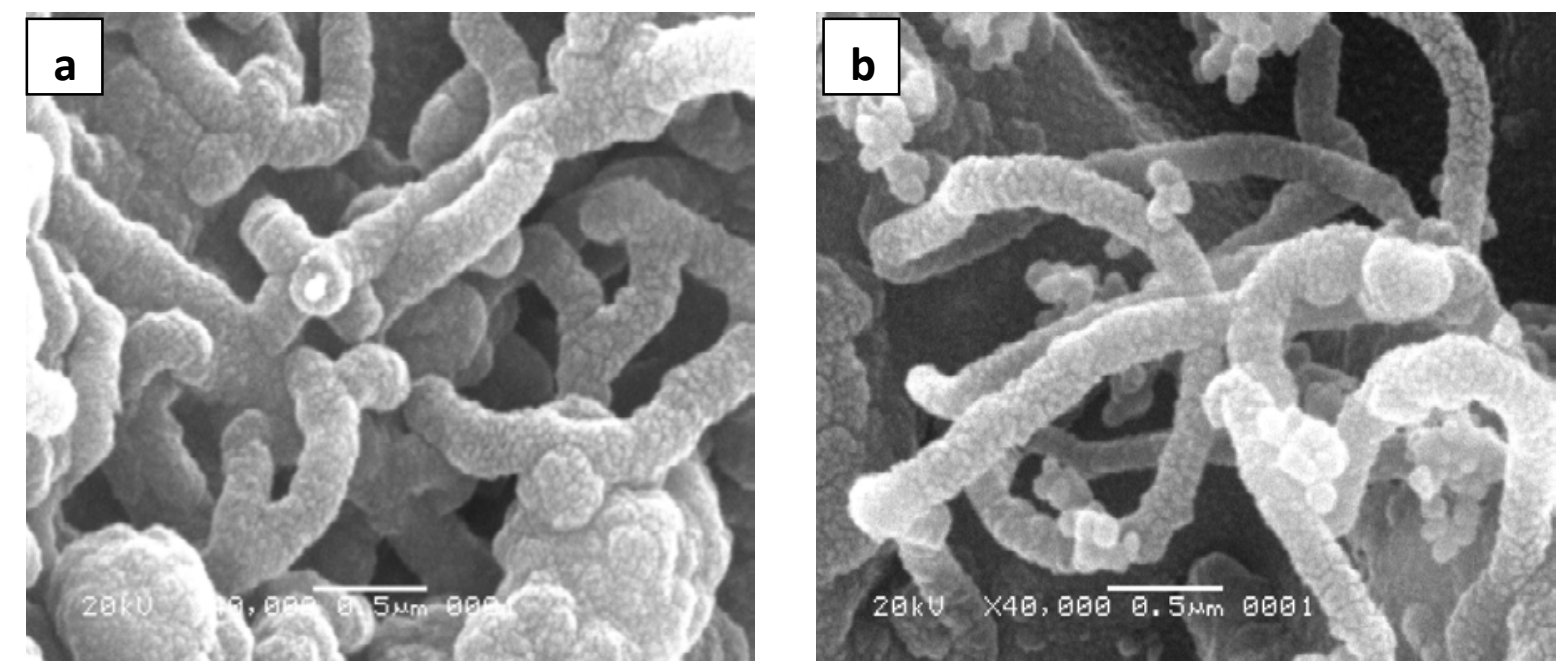

Gambar 3. Hasil foto SEM CNT dengan perbesaran 40.000x (a) katalis Co/Zeolit 3\%, (b) katalis Co/Zeolit 3,5\% 

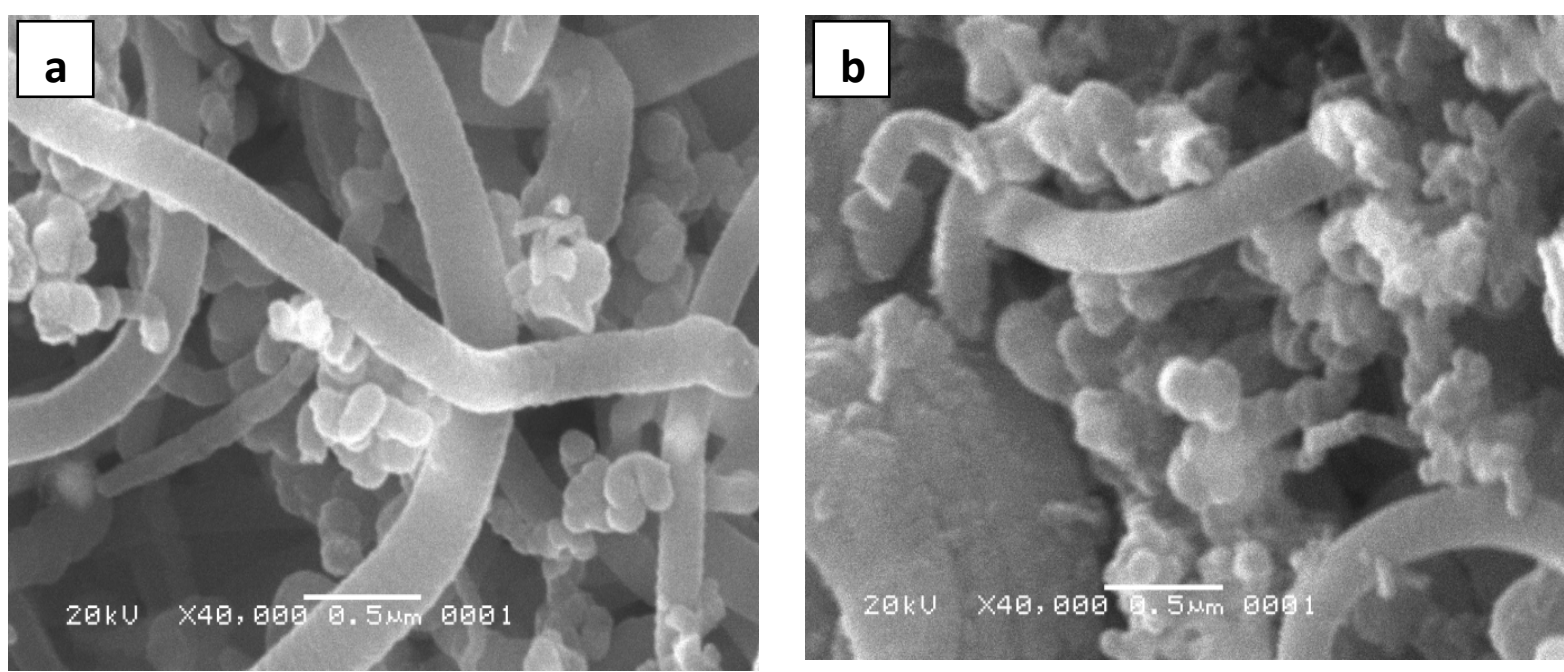

Gambar 4. Hasil foto SEM CNTs dengan perbesaran 40.000x (a) katalis Fe/Zeolit 3\%, (b) katalis Fe/Zeolit 3,5\%

Pada suhu $700^{\circ} \mathrm{C}$ katalis $\mathrm{Fe}$ mempunyai spesifik energi permukaan yang tinggi sehingga lebih banyak menghasilkan produk CNTs. Katalis Fe juga mempunyai sifat fleksibilitas yang luas tergantung kondisi dan lebih mudah pecah (Salim, 2003). Dengan sifat yang lebih mudah pecah, maka ketika di reaksikan dengan gas asetilen pada suhu tinggi, Fe akan lebih mudah bereaksi dan lebih banyak menghasilkan CNTs.

Selain katalis utama, komposisi penyangga katalis juga berpengaruh dalam besar kecilnya hasil produk CNTs. Dapat dilihat bahwa pada komposisi penyangga katalis yang besar maka jumlah hasil CNTs yang didapatkan akan besar pula. Zeolit sebagai penyangga katalis juga mempunyai kemampuan untuk mengadsorp gas asetilen (carbon feedstock) pada suhu tinggi dimana rongga-rongga molekulnya mempunyai gugus aktif di dalam saluran antar kristal sehingga baik untuk penyangga katalis. Ketika komposisi Zeolit diperbesar, gugus aktif-pun semakin banyak, maka luas permukaan untuk tempat menempelnya CNTs akan lebih besar. Besarnya karbon yang dapat diikat oleh penyangga katalis inilah yang mempengaruhi hasil sintesis CNTs dengan metode CCVD.

Hasil analisa SEM pada Gambar 3-4 menunjukan bahwa jenis promotor katalis akan mempengaruhi proses penumbuhan karbon nanotubes pada sistem catalytic chemical vapour deposition. Terukur pada Gambar 4a dengan diameter 200 nm, Gambar 3b dengan diameter 150 nm, Gambar 4a dengan diameter $125 \mathrm{~nm}$, serta Gambar 4b dengan diameter $100 \mathrm{~nm}$. Diameter karbon nanotubes yang terbentuk ada pada kisaran angka relatif besar yang merupakan gambaran dari adanya penggabungan dinding yang terbentuk menjadi satu. Ukuran partikel katalis sangat berpengaruh pada diameter nanotube karbon yang terbentuk. Semakin besar penambahan komposisi atau konsentrasi katalis, maka diameter karbon nanotubes akan semakin besar pula. Penambahan konsentrasi katalis mempengaruhi perubahan struktur dan diameter CNTs (Nur, 2009).
Diketahui pada komposisi yang sama, katalis Fe/Zeolit menghasilkan diameter karbon yang paling besar dibanding dengan katalis Co/Zeolit. Hal ini dikarenakan karena sifat katalis Fe yang mempunyai permukaan aktif yang lebih besar dalam proses dekomposisi karbon dan lebih mudah terurai, sehingga ketika ditambah dengan penyangga katalis Zeolit yang juga mempunyai gugus-gugus aktif pada molekulnya maka diameter karbon nanotube yang terbentuk besar.

Mekanisme pertumbuhan karbon nanotubes sebenarnya tidak diketahui secara pasti. Sampai sekarang, mekanisme pertumbuhan masih menjadi perdebatan dan secara umum ada dua pendapat yang bisa diterima oleh para peneliti sebagai dasar mekanisme pertumbuhan carbon nanotubes (Laurent dkk., 1998 dan Lee dkk., 2001). Pada penelitian yang dilakukan ini mekanisme pertumbuhan karbon nanotubes mengacu pada "base growth model". Pertama asetilen sebagai sumber karbon akan terdekomposisi menjadi sebuah karbida $\mathrm{C}_{2}$ (fullerenes) pada permukaan logam katalis aktif. Partikel karbida akan berdifusi masuk ke dalam logam partikel. Partikel karbida yang tidak stabil ini di dalam logam akan segera membentuk suatu karbon seperti tangkai. Pembentukan karbon bertangkai secara cepat ini disebabkan karena ikatannya dengan penyangga logam adalah sangat lemah. Setelah itu terjadi proses graphitisasi secara perlahan dari dindingnya yang menyebabkan karbon nanotubes terbentuk memanjang.

\section{KESIMPULAN}

Merujuk pada hasil penelitian yang didapatkan maka dapat disimpulkan bahwa CNTs telah dapat dihasilkan dengan menggunakan proses CCVD dengan katalis cobalt dan ferrum. Dalam sintesis CNTs dengan berat katalis dan kondisi operasi yang sama, tetapi konsentrasi komponen aktif pada katalis yang berbeda memberikan pengaruh terhadap diameter dan berat produk CNTs yang dihasilkan. Sintesis Carbon Nanotubes (CNTs) dengan konsentrasi komponen 
aktif katalis yang berbeda memberikan pengaruh terhadap diameter dan berat produk CNTs yang dihasilkan. Semakin besar konsentrasi komponen aktif katalis, maka diameter CNTs yang dihasilkan semakin besar. Namun, berat produk yang dihasilkan semakin sedikit. Penggunaan katalis Co/Zeolit dan katalis Fe/Zeolit memberikan pengaruh yang berbeda pada sintesis Carbon Nanotubes (CNTs), dimana pada Carbon Nanotube (CNTs) yang menggunakan katalis Fe/Zeolit mempunyai diameter yang lebih besar daripada Carbon Nanotubes (CNTs) yang menggunakan katalis $\mathrm{Co} /$ Zeolit dengan tipe Carbon Nanotubes (CNTs) yang dihasilkan adalah Multiwalled Nanotube (MWNTs). Faktor lain yang tidak kalah penting adalah perlakuan kalsinasi pada katalis yang akan digunakan pada proses sintesis CNTs. Katalis yang tidak dikalsinasi saat preparasi katalis tidak akan menghasilkan Carbon Nanotubes (CNTs) dalam proses catalytic chemical vapor deposition (CCVD). Proses purifikasi perlu dilakukan agar diperoleh Carbon Nanotubes (CNTs) dengan kualitas yang baik bebas dari impuritas.

\section{DAFTAR PUSTAKA}

Audier, M., Oberlin, A., and Oberlin, M., (1981), Morpholog and crystalline order in catalytic carbon, Carbon, Vol. 19, pp. 217-224.

Baker, R.T.K., Harries, P.S., and Thomas, R.B., (1973), Formation of Filamentous Carbon Fromiron,Cobalt and Chronium Catalysed Decomposition of Acetylene, Journal of Catalysis, 30, pp. 86.

Chiangga, S.S.N. and Nilsaengrat, P., (2009), Effect of suhue on carbon nanotubes growth on thin Iron film by thermal chemical vapor deposition method under low pressure, Physics Procedia.

Iijima, S., (1991), Helical Microtubes of Graphitic Carbon, Nature, 354, pp. 56-58.

Ijima, S. and Ichihashi, T., (1993), Single-shell carbon nanotubes 1-nm diameter, Nature, 363, pp. 603.

Guo, T., Nikolaev, P., Thess, A., Colbert, D.T., and Smalley, R.E., (1995), Catalytic growth of singlewalled nanotubes by laser vaporization, Chemical Physics Letters, 243 (1,2), pp. 49-54.

Laurent, C., Flohaut, E., Peigney, A., and Rousset, A., (1998), Metal Nanoparticles for The Catalytic Synthesis of Carbon Nanotubes, New Journal of Chemistry, pp. 1229-1237.

Lee, C.J., Lyu, S.C., Cho, Y.R., Lee, J.H., and Cho, K.I., (2001), Diameter-controlled growth of carbon nanotubes using thermal chemical vapor deposition, Chemical Physics Letter, pp. 245-249.

Mikrajuddin, A., Sukirno, Khairurrijal, Fatimah, A. Noor, L.L.. Zaenufar, dan Yulkifli, (2009), Kajian Pembuatan Nanotube Karbon dengan Menggunakan Metode Spray Pyrolysis, Jurnal Nanosains \& Nanoteknologi, Vol. 2, No. 1.

Nur, A., (2009), Karbon Nanotube Dari Limbah Cair Pabrik Alkohol Dengan Metode Chemical Vapor Deposition, Prosiding Seminar Nasional Teknik Kimia Indonesia.

Salim, A., (2003), Analisa Teknik Kilang Gas To Liquids (GTL) untuk Pengembangan Lapangan Gas.

Subagio, A., Pardoyo, Ngurah A.K., Gunawan, V., Sony, dan Rowi, (2009), Studi Suhu Penumbuhan Carbon Nanotubes (CNT) yang Ditumbuhkan Dengan Metode Spray Pyrolisis, Jurnal Nanosains \& Nanoteknologi, Vol. 2, No. 1.

Tee, C.J., Madzlan, A., and Ismail, A.F., (2008), Effect of reaction suhue and flow rate of precursor on formation of multi-walled carbon nanotubes, Jurnal Teknologi (49F), pp. 141-147.

Tee, C.J., Madzlan, A., and Ismail, A.F., (2009), Influence of Catalyst Preparation on Synthesis of Multi-Walled Carbon Nanotubes, IEICE Transactions on Electronics, Vol.E92-C, No.12, pp.1421-1426.

Wang, T. and Wang, B., (2006), Study On Structure Change of Carbon Nanotubes Depending On Different Reaction Gases, Applied Surface Science, 253, pp.1606-1610.

Wardhani, S, (2008), Studi Pengaruh Konsentrasi Zn (II) Pada Preparasi Katalis Zeolit-ZnO Terhadap Oksidasi Fenol, Jurusan Kimia, FMIPA, Universitas Brawijaya, Malang.

Wei, Y.Y., Eres, G., Merkulov, V.I., and Lowdens, D.H., (2001), Effect of Film Thickness on Carbon Nanotubes Growth by Selective Area Chemical Vapour Deposition, Applied, Physic Letters, 78, pp. 1394-1396.

Zaretskiy, S.N., Young-Kyu, H., Dong, H., Ji-Hyun, Y., Jinwoo, C., and Ja-Yong, K., (2003), Growth of carbon nanotubes from Co nanoparticles and $\mathrm{C}_{2} \mathrm{H}_{2}$ by thermal chemical vapor deposition, Chemical Physics Letters, 372, pp. 300-305.

Zheng, B., Li, Y., and Liu, J., (2002), CVD Synthesis and Purification of Single-walled Carbon Nanotubes On Aerogel-Supported Catalyst, Applied Physic. A., 74, pp. 345-348. 